\title{
CENSORSHIP AT COMMON LAW AND UNDER MODERN DISPENSATION *
}

\section{Garrard GLENN $\dagger$}

At present this subject is outmoded, becattse we seem to be on the last lap of our escape from the horrors that followed the so-called Great War, of which the worst, perhaps, was the effort to make all American minds of one pattern. That, of course, is the object of censorship in both its forms. For, broadly speaking, there are but two kinds of censorship. One may be described as gentle, because it acts by way of suggestion only; the other being coercive, its handmaiden is the law.

With the gentle variety of censorship discussion cannot go far. It needs only to be described in order to be laid aside; and our leaders, both of the late and of the present regime, have defined it by their suggestions. Thus one of our statesmen (now departed) indicated that prosperity would return if only some one would write a song for all of us to sing togetherthe song relating to our inherent virtues as good Americans. Nobody wrote quite such a song, and we have managed to get along without, so far. On the other hand, in our efforts to end the depression a new idea was hit upon. We should not speculate, using that term not only "marketwise," as the brokers have it, but in its older and broader meanings as well. On the contrary we must be of good cheer, put our shoulders to the wheel, do all the other things that were done, and submit to all the nonsense that was suffered when we were selling Liberty Bonds.

The other sort of censorship appears when the law is used in an effort to make people think alike on other subjects than prosperity. This impulse is always with us. Although we are either free or getting free of some statutes that have ruled us since the Great War, it might be well to remember that, in our common law, censorship still retains an important place. It is flexible indeed; recently our bonds have been loosened. But, because the frame is apt to be tightened as soon as returning prosperity gives one school of thought and habit a chance to reflect on how hateful are the ideas of another, perhaps it might not be out of place to ask, what place does censorship, as such, have in our common law system, and how did it get there?

To answer, one must deal with many movements that at one time or another were translated into action by means of statutes and rules of law.

* Being the substance of an address presented at a meeting of the Virginia Bar Association, August I2, I933. Some of the remarks are to be appraised as of that date.

$\dagger$ A. B., I899, University of Georgia; LL. B., r903, Columbia University; Associate Professor of Law, I9r3-2I, Columbia University; Professor of Law, University of Virginia; member of the New York and Virginia bars; author of articles in legal periodicals. 
I am not original in suggesting that behind all these efforts are only one or two simple impulses. There is, of course, religion. But more powerful, there is State policy, non-moral in essence, but glazed with a claim of morality or religion sufficient to excite applause at the burnings. And lastly, there is the attempt to protect morals as such. I say lastly, because in our own history it comes last in order of development. Let us take these in order.

Censorship as a matter of State policy, as we all know, is based on the effort to keep going a plan that has been determined upon by those in power. Hence, in the course of years, the same idea will offend different schools. Thus not only was James I of England moved to action by a Jesuit writer named Suarez, who argued that the State as such, so far from being sacred, was merely an institution devised by common consent to serve public uses; but in the reign of the Most Christian King, Louis XV of France, this work was again burned by the common hangman-at Paris, however, instead of London. ${ }^{1}$ The same likeness appears in the picture so admirably drawn by Sir William Holdsworth, a living historian of our law, as to the origin and use of State censorship in England. In an article ${ }^{2}$ which I can only summarize here he shows us how the Tudors discovered a very effective method of censorship, how the Stuarts continued in the enjoyment of the practice, and then, most interesting of all, how the Puritans, when they came into power under Cromwell, found the idea so admirable that they did not list censorship among the abominations which God had appointed them to destroy. I have only one comment to offer: the manner in which this species of censorship was created was quite characteristic of the method of growth of our legal institutions, the bad as well as the good. And so let us see how it was done.

Looking around them, the Tudors found a trade guild which had existed since the fourteenth century. This guild, finally incorporated as the Stationers' Company in I 556, was composed originally of "limners" (that is, those who illuminated manuscripts,-illustrators, as we would call them), and writers of texts, the latter being succeeded, after printing became common, by printers. As these craftsmen also sold their products, the writer went to them with his manuscript as today he goes to the publisher. This guild having the monopoly of publishing in all its parts, printing, illustrating and selling,-it followed that the author, once his manuscript was accepted, shared the monopoly in the publication and sale of the book which the Stationers' Company enjoyed. Now, to convert this institution, which had originated as a device for the protection of author and publisher, into an engine for the suppression of all thought not spon-

${ }^{1}$ See $z$ Letters of Junius (Bohn ed.) I75, letter signed "Bifrons", April 23, I768.

" Holdsworth, Press Control and Copyright in the I6th and I7th Centuries (1921) 29 YALE L. J. 84I. 
sored by those in power, it was only necessary to confirm the Company of Stationers in its monopoly and then to forbid its issuing a book without the imprimatur of government. And so, by Star Chamber ordinances of I586 and I637, there were to be no presses in England, save those that were licensed by the Crown, and registered with the Stationers' Company. The latter was given power "to search for and deface offending books, presses and type," and no books could be imported from abroad save those approved by the Crown. In short, as that courtier, Bacon, observed (doubtless with his tongue in his cheek), books were "but the licensed manners of the times"; and old John Selden grumbled, a little later, that a man's reading was wholly to be determined by a customs officer. ${ }^{3}$ Of course there were bootleggers, but their cases were for the Star Chamber.

As I have said, the Puritans, although they abolished the Star Chamber, were pleased to continue the practice of licensing. It is intriguing, then, to note two incidents of this period. Despite his noble essay, Areopagitica, wherein he urged that the licensing system be abolished, Milton did not in practice support the idea that all ideas be allowed to go free of prosecution. By no means. And although he was no adherent of the licensing system, Milton, like many a politician of our late darkness who did not venerate prohibition, accepted a job which included all the duties of a censor. At an earlier date Roger Williams, who believed that freedom of thought, as well as of belief, at last had struck England, came over from Rhode Island and published a pamphlet on government. But Williams' views were no more pleasing than would have been those of $\mathrm{Mr}$. Jefferson. So outraged, indeed, were the saints at the helm that Williams hastily left England for the more congenial shores of Narragansett Bay, leaving his book to be burned by the common hangman. ${ }^{4}$

Throughout the Restoration period, naturally enough, this system of licensing continued. The bootlegging problem, however, was more serious, because the Star Chamber, with its efficient system of criminal equity, had been abolished by a statute passed in Cromwell's time, and public opinion would not permit a re-establishment of it. But the common law judges hit upon the idea of using the Court of King's Bench for the necessary purpose, and accordingly they met in convention and agreed

“. . . unanimously, that all persons that do write, or print, or sell any pamphlet that is either scandalous to public or private persons, such books may be seized and the person punished by law; that all

${ }^{3}$ Selden, Table Talk, tit. Books, Authors, 4.

4 Masson, Life of Milton (1877) 324-325; 3 id. II2-I19; ERnst, Roger Williams (1932) 234 ff. "An extremely curious fact in the history of Milton's secretaryship (he was "Latin Secretary", or translator, in what latter day Englishmen would call the Foreign Office) is that through the whole of this year $165 \mathrm{I}$ he acted as an official licensor or censor of the press. That the author of the Areopagitica should be found in such a capacity is certainly a surprise. The evidence, however, is incontestable, nor is the explanation difficult." 4 MLasson, loc. cit. supra. 
books which are scandalous to the government may be seized, and all persons so exposing them may be punished." 5

These are the words of Scroggs, Lord Chief Justice of the King's Bench, of whom Sir Walter Scott has given us a portrait in Peveril of the Peak. Yet, to show that his heart was in the right place (which sometimes means in two places at once), this judge, at the same time that he was hounding into conviction those who were accused by Titus Oates of complicity in his "Popish Plot", pleased a king whose leaning was towards Catholicism by causing a rule to be issued by the King's Bench confiscating a book against "Popery" whereof one Carr was the author. For this Scroggs was later impeached. But the articles were never pressed to trial; probably because, as the chatty Roger North later declared, all Scroggs had attempted was to treat the King's Bench as the successor of the Star Chamber. ${ }^{6}$ That was merely a judicial error. Our Supreme Court has also erred at times.

Nor did this system end with the revolution of I688. It continued until I694, when Parliament, at long last, refused to continue the licensing system save only as to plays; and confined the monopoly of books to the Bible and the Book of Common Prayer. As to government, all that was left was prosecution, by way of indictment or information, for a seditious libel; there was no preventive censorship. Thus was secured the "freedom of the press", dear to the hearts of eighteenth century lawyers on both sides of the Atlantic, and carefully preserved by express mention in our constitutional Bill of Rights. ${ }^{7}$ And so matters continued until the Great War.

Let us now turn to the censorship that professedly is based on morality. Interestingly enough, this sort of action moved the common law courts just about the time when political censorship ended. Prior to the Restoration, none of the king's courts, whether at common law or in equity, had been called upon to deal with such matters. It is quite true that during the reign of Charles II it was held by no less a judge than Sir Mathew Hale that the public utterance of blasphemous words constituted a crime punishable at common law; likewise with seditious language. ${ }^{8}$ And so, as was held in a famous case of the Restoration period, with Sir Charles Sedley's public

'Carr's Case, 7 How. St. Tr. IIII (I680); Impeachment of Scroggs, 8 id. at I98 (I680).

- "I do not remember much agitation about the reason upon which the court of King's Bench took this authority of making a provisional order upon them; but it seems grounded upon that law which takes away the Star-Chamber; for it is therein declared, or the judges have resolved, that all jurisdiction which the Star-Chamber might lawfully exercise rested by law in the court of King's-Bench." 8 How. St. Tr. 165.

${ }^{7}$ Burdick, LAW of THE Constitution (I922) $349 \mathrm{ff}$.; Holdsworth, supra note 2; 2 Stephen, History of the CRIMINAL Law (I883) $309 \mathrm{ff}$.

${ }^{8}$ Taylor's Case, I Vent. 293 (1676). See also People v. Ruggles, 8 Johns. 290 (N. Y. I8II) ; Updegraff v. Commonwealth, II S. \& R. 394 (Pa. I824). 
acts of indecency. ${ }^{9}$ But these were cases of disorderly conduct, easy for a lawyer to understand; and it was not until I 727 that the rule was extended to indecent publications. This was done in the case of the publisher Curl (Alexander Pope's particular aversion), who was prosecuted in 1727 for publishing a book called Venus in a Cloyster, or The Nun in Her Smock. The court, after considerable hesitancy, held that the publication of this book was a crime at common law, and so Curl stood in the pillory-"as he well deserved," adds the learned Strange, who had been his counsel. ${ }^{10}$

This decision settled the law for both England and our country, that the criminal courts can entertain a prosecution of one who publishes an indecent book. But the case involved a difficulty which becomes apparent when we recall an earlier decision that writing an obscene book was not indictable. Lord Holt thought that jurisdiction lay elsewhere. "There are ecclesiastical courts," said he; "why may this not be punished there?" Again, "This may be said to be a temptation to incontinence, and therefore why not punishable in the ecclesiastical court?" 11 Thus Lord Holt pointed back to a time when the common law, that is, the law administered by the king's courts, had nothing to do with the offense of obscenity. This answers the question which many a student of the period has doubtless asked. Why was it that the press censorship of Tudor, Stuart or Puritan, indifferently, was never concerned with immorality? But if we recall that the older Church in all her acts from the crusade against the Albigenses, drove primarily against heresy, we will have the answer. For the obscene, as distinct from the heretical, the Church had a separate and milder machinery. In last resort, any such outrage, whether by word or act, was for the Church to handle, not the secular courts with which we are familiar.

In her operations touching "the soul's health" of delinquents, small or great, the Church had two great instruments, the confessional and the ecclesiastical courts. As the obscene certainly touched "the soul's health", the Church dealt with it. But because there was the confessional as well as a system of ecclesiastical courts, I suggest that there was probably, little business for the Church courts. Just as the experienced line offiçer of our army so often administers summary justice with the consent of the offender, and thus saves him from being sent up for court-martial, so the ecclesiastical courts of the Middle Ages probably had little criminal business of this sort, the parish priest saving them such cases by the imposition of public penance or by practical means of a secular nature. ${ }^{12}$

- Sir Charles Sedley's Case, I7 How. St. Tr. I55 n. (I663).

${ }^{10}$ Curl's Case, 2 Strange 788 (I727), overruling Regina v. Read, II Mod. I42 (I707).

11 Regina v. Read, supra note ro.

12 "Documents preserved almost by chance clearly show that a vast number of small cases-police cases, we should call them-were in pre-Reformation days arranged by the ecclesiastical authority. Disputes, brawls, libels, minor immoralities, and the like, which nowadays would have to be dealt with by the local justices of the peace or by the magistrates at quarter sessions, or even by the judges at assizes, were disposed of by the parson and the 
But, whatever may be true on that score, the fact remains that the common law courts had no idea of what to do with an indecent act or word until long after the Reformation. Then it was that circumstances forced them to act. The ecclesiastical courts, indeed, had remained; but, for reasons not here of importance, it became evident, especially in the lurid glare of Restoration days, that cognizance of the obscene could no longer be refused by the King's Bench.

In the course of this process another Tudor-Stuart ghost was exorcised. For while the King's Bench took over this new jurisdiction, the other great court of the king himself, the Chancery, played quite a minor part. It is quite true that soon after the first copyright act had been passed, Lord Macclesfield, a courtly chancellor who, like Bacon, ended with an impeachment for bribe taking, enjoined an English translation of Burnett's Archoologia sacra, on the ground that, although translation was not included in the rights reserved to the author by the statute, "yet this being a book which to his knowledge (having read it in his study) contained strange notions, intended by the author to be concealed from the vulgar in the Latin language, in which language it could not do much hurt, the learned being better able to judge of it, he thought it proper to grant an injunction to the printing and publishing it in English; but he looks upon it, that this court had a superintendency over all books, and might in a summary way restrain the printing or publishing of any that contained reflections on religion or morality." 13 But although this idea was repeated by Lord Ellenborough in a dictum nearly a century later, ${ }^{14}$ the difficulty was that it proceeded from the assumption that "the Chancery was a Court of State." This idea may have been an unconscionably long time adying, to use the pleasant expression of the good-natured king in whose reign it was nurtured; but Coke in his time had so mortally wounded the conception that its death finally came; ${ }^{15}$ and so the Chancery, as such, is no forum of

parish. It may not have been an ideal system, but it was patriarchal and expeditious." GASQUET, ENGLAND ON THE Eve of the Reformation (I900) 307. I cannot find in Coulton's two volume collection, LIFE IN THE MIDDLE AGES (I928), anything that is even suggested as refuting this particular statement, although Mr. Coulton's work, as he himself states, was inspired by a desire to refute the view of the Middle Ages that was entertained by such writers as Gasquet and Gairdner. I am further fortified in this conclusion by the fact that Messrs. Ernst and Seagle, neither members of the Church nor particularly friendly in that regard, say that in "the Age of Faith the Church in its supervision of literature concerned itself almost entirely with its main interest, the extirpation of heresy. It naturally assumed that if one were a good son of the Church, the rest would be unimportant. A really good Catholic could commit no wrong which need alarm the Church. When the Catholic Church arose, it had combated the lusts of the flesh and the carnalities of Paganism. In its confessionals it dealt daily with such sins." ERNST AND SEAGLe, To THE PuRE (I929) I4I. Further, the INDEx, first published in 1559 (but never published to this day in English-speaking countries) drove against heresy, not obscenity; id. at I4I $f f$.

${ }^{13}$ Burnet v. Chetwood, 2 Mer. 44 I n. (1720).

14 Du Bost v. Beresford, 2 Camp. N. P. 5 Ir (I8ro).

I5 See Chafre, Cases on Equitable Retref against Torts (I924) 24, 88. I also venture to refer to my paper on Coke, Edward Coke and Law Restatement (I93I) I7 VA. L. REv. 447,456 . 
morals, as we all recognize today. ${ }^{16}$ The furthest an equity judge can go is to deny protection to the copyright of a book which he deems to be immoral-an idea which Lord Eldon put into effect with great gusto as to certain works of Byron and Southey, and still finds expression in this country, or to enforce specific performance of a contract relating to the publication of a book. Within its own appointed domain an equity court, of course, may set a high standard of right living and action. ${ }^{17}$ But when a book happens to be the subject matter of a contract or trust, the morality of the book is, in a sense, collateral. While an equity court will act in the protection of property, it cannot be required to affirm an illegal act; and so the only question the chancellor must answer is whether the book is of such character that the sale of it would violate the criminal law. ${ }^{18}$ If so, it is not property; and rights with regard to it are entitled to no protection. Thus, in the end, we are referred to the criminal court as the custodian of our morals.

But here we find in our twentieth century the same point presenting itself that appealed to those who governed in the far-off days of the Tudors, the Stuarts and the Puritans. Censorship will not work effectively if one uses only the regular machinery of criminal procedure. You may convict a certain man for publishing a book under censure; but the book remains for another person to sell, and the plates are always there for new imprints. That happened, for instance, with Paine's Age of Reason, so violently condemned by English courts during the war with revolutionary France. Two different publishers were convicted at different times because of this book, ${ }^{19}$ but the plates remained. So the same old thing was needed-not only the arrest of the author or dealer on a warrant sworn out against him, but also

16 "I have no hesitation in saying that Lord Macclesfield was wrong when he said in Burnet v. Chetwood that "the Court of Chancery has a superintendency over all books, and might in a summary way restrain the printing or publishing of any that contained reflections on religion or morality.' So I have no hesitation in saying that Lord Ellenborough was wrong when he laid down in $\mathrm{Du}$ Bost v. Beresford that 'the Lord Chancellor would grant an injunction against the exhibition of a libellous picture." " Lord Campbell in Emperor of Austria v. Day, 3 De G. F. \& J. 2I7 (I86r). So, on a bill to set aside a trust created by plaintiff's testator for a concubine, Lord Selborne said: "So far as the power of moral censorship is committed to any of the courts of this country, it belongs, not to this but to a different jurisdiction." Ayerst v. Jenkins, L. R. I6 Eq. 275 (1873). See also the judgment of Lord Cairns in Prudential Ins. Co. v. Knott, L. R. Io Ch. App. 42 (1875), as to the absence of power in the Court of Chancery to "interfere as a censor morum".

${ }_{17}$ Thus: "A trustee is held to something stricter than the morals of the market place. Not honesty alone, but the punctilio of an honor the most sensitive, is then the standard of behavior. As to this there has developed a tradition that is unbending and inveterate." Cardozo, C. J., in Meinhard v. Salmon, 249 N. Y. 458,464, I 64 N. E. 545,546 (I928).

${ }^{18}$ Southey v. Sherwood, 2 Mer. 435 (18r7) ; Murray v. Benbow, 6 Petersd. Abr. 558n. (I822); Rogers, Copyright and Morals (I920) I8 MrCH. L. Rev. 390. Modern illustrations occur where the court is asked to protect a book by injunction against pirating, or the receiver of a publishing house asks leave of court to sell books which have come into his possession. In such cases the court must decide whether the book is of such character that its sale would violate the criminal law. Re Worthington, 30 N. Y. Supp. 363 (I894); St. Hubert's Guild v. Quinn, 64 Misc. 336, Ir8 N. Y. Supp. 582 (I909).

${ }^{20}$ Eaton's Case, 22 How. St. Tr. 753 (I793); William's Case, 26 id. at 653 (1797). 
the impounding of the book itself. I say impounding, because while seizure may thus be made in advance of a trial, the offending sheets or plates should not be destroyed unless there is a conviction of the prisoner.

The model for this sort of legislation is an English statute, which dates from 1857; and our states have laws of similar tenor, however they may vary in form. It is interesting, as Messrs. Ernst and Seagle tell us, that the sponsor and draftsman of this law in England was Lord Campbell, himself a "great lover of literature, who acknowledged her as a mistress hardly second to the law." 20 These laws actuate the seizures of which from time to time the newspapers inform us. And do not let us suppose that these prosecutions and seizures are confined to this country. $\mathrm{Mr}$. Comstock's Society in New York is of respectable age, I know; but the English Society for the Suppression of Vice dates from 1802 . Its functioning is mostly to be seen in cases that are reported in regular books. I remember that in I929, while I happened to be in London, the evening newspapers blazed with an account of proceedings before Mr. Mead, the magistrate at the Marlborough Street Police Court, the subject being thirteen paintings which had been put on private exhibition, and the artist being the late D. H. Lawrence, who, like Mr. Wegg, had dropped into art. The proceedings were dropped on the defendants giving an undertaking not to show the pictures again, ${ }^{21}$ and thus $\mathrm{Mr}$. Lawrence withdrew from art. Qualis artifex pereat!-so his admirers may have thought, but Mr. Mead evidently was not of that opinion.

Preventive censorship is further secured by closing the mails to matter of this sort. The English do it by an act of Parliament; and we do it by means of an act of Congress, the mails being federal business. ${ }^{22}$ But that is not all. By an amendment to the Tariff Act of 1922 the importation of obscene matter was made a federal offense, there being added the usual powers as to seizure and impounding pending trial. ${ }^{23}$ And hardly had the motion pictures become an institution with us than there appeared, as a matter of state legislation fully upheld by the Supreme Court, a licensing system closely corresponding to the control which in England is exercised by the Lord Chamberlain over plays. ${ }^{24}$

${ }^{\infty}$ Ernst and Seagle, op. cit. supra note 12 , at im ; Obscene Publications Act, 20 \& 2I Vict. c. 83 (1857). For types of American statutes, see N. Y. Penal Law (Ig09) $\S \S$ II4I ff.; VA CODE ANN. (Michie, 1930) $\$ \$ 4549,4820-22$; W. VA: CODE (I932) $\$ \$ 6066$, 6164 .

${ }^{21}$ London Daily Express, Aug. 9, I929.

$\approx$ For England see Post Office Protection Act, 48 \& 48 Vict. c. $76, \$ 4$ (I\&84); Rex v. De Marny (1907) I K. B. 388. Our statute is 35 Stat. II29 (I909), I8 U. S. C. A. § 334 (I926).

${ }^{23}$ Act of Sept. 2I, I922, c. 356, tit. III, $\$ 305$ (a) and 305 (c), 42 STAT. 936-37 (1922), 19 U. S. C. A. $\$ \$ 135-36$ (I926).

is Mutual Film Corp. v. Industrial Commission, 236 U. S. 230, 35 Sup. Ct. 387 (1915); Mutual Film Corp. v. Hodges, 236 U. S. 248, 35 Sup. Ct. 393 (I915); noted as to decision below in Note (1914) 2 VA. L. REv. 216. 
Such is the machinery provided for censorship over the pornographic. In method, as we have seen, it resembles the older censorship over the press. But that there is a wide difference between the two is apparent when we consider not only the persistence of the new form of censorship, despite the many able and clever attacks that it has borne, but also the attitude of our courts toward it. In the latter, indeed, lies its strength. In a brief survey of this branch of case law we may ascertain, perhaps, why censorship against pornography remains, while national prohibition is in the discard.

The difference, I think, lies in this, that censorship as to pornography takes account of mores. This was shown long ago when the Massachusetts court held that a theatrical production was not to be deprived of equitable protection simply because the founders of the colony on Massachusetts Bay thought that plays were the Devil's toys. On the contrary, as "we do not so regard them, the reason ceasing, the rule ceases with it." ${ }^{25}$ And I am sure that no court today would agree with the learned and pious editor of the Newgate Calendar, who after observing that a malefactor in I76I had diverted himself with reading the Beggars' Opera, observed:

"We cannot conceive but that this play, however witty and however applauded, has tended, beyond any piece of writing, to increase the number of thieves. Young fellows have thought it right to copy Mackheath, because Mackheath is represented as a gentleman highwayman." 26

And so, working along the line that manners change, and we change with them, the courts of England and America have worked out rules that are simple and (on the whole) satisfactory. Let me enumerate them.

In the first place, the question is whether a book, play or other work of art offends against the common law as now embraced in our statutes, for the statutes do not add to the common law definition. ${ }^{27}$ And, as we know, the common law, unlike statutes, has in it always the possibility of change. Let me give an example. It is often argued that, as it has been in cases of criminal libel ever since Fox's Libel Act, the jury should be the ultimate judge of all questions, law as well as fact, as to the decency of the work under consideration. That point is emphasized by the "Clean Books Bills" at one time offered in our state legislatures; and it is supported by two decisions of fifty odd years ago. ${ }^{28}$ But the idea will not work, because in

$\approx$ Keane v. Kimball, r6 Gray 545 (Mass. I860).

${ }^{\circ} 4$ Newgate Calendar 197 (Trial and Execution of Isaac Darking).

${ }^{2}$ See, for English cases, Rex v. Delaval, 3 Burr. I434 (1763) ; Eaton's Case, 3r How. St. Tr. 927 (I812); William's Case, supra note I9; Reg. v. Hicklin, L. R. 3 Q. B. 360 (I868); Steele v. Brannan, L. R. 7 C. P. $26 \mathrm{r}$ (1872); Bradlaugh v. The Queen, 3 Q. B. D. 607 (I878); for American, Commonwealth v. Sharpless, 2 S. \& R. 9I (Pa. I8I5) ; Commonwealth v. Holmes, I7 Mass. 336 (I82I) ; Commonwealth v. Tarbox, I Cush. 66 (Mass. I848); People v. Ruggles, supra note 8; Moens v. U. S., 267 Fed. 317 (App. D. C. I920); U. S. v. Males, 5 I Fed. 4 I (D. Ind. I892).

${ }_{2}$ U. S. v. Bennett, I6 Blatchf. 338, Fed. Case No. I457I (1879) ; People v. Muller, 96 N. Y. 408 (1884). 
many cases where the question arises the court is sitting in equity and therefore no jury is present; and even in criminal cases and those civil cases where a jury is present the court must decide whether the book is illegal as a matter of law, which means that, if the jury should say otherwise, its verdict would not be allowed to stand. ${ }^{29}$ And so, in the last analysis, it is the court which says that a book is moral or immoral, as the case may be. That removes the sting of the rule, also well established, that if the case does go to the jury, expert evidence in the shape of opinions of critics and authors will not be received. But the judge, to whom first of all the point is directed, may resort to expert evidence in the shape of what critics have written, and to the use of his own critical faculty. Thus in the sale of a set of Voltaire, where the buyer refused to pay for what he had bought on the ground that his agreement was illegal, Judge Seabury, of the New York Supreme Court, holding that the contract was lawful, because in his judgment Voltaire's works were not within the ban of the criminal law, referred to the opinion of critics as diverse in competency as Condorcet and Frederick the Great. And the New York Court of Appeals, in appraising the legality of Gautier's Mlle. de Maupin, allowed the jury to pass upon the book, only because competent critics had differed so widely. ${ }^{30}$

That being so, of course the court must guard against any idea as to "what is good for people to read". If Henry Fielding had been committed by his own Bow Street Office to stand trial for obscenity in the creation of Tom Jones, the development of the English novel would have been forestalled; which could not be outweighed by the fact that eighteenth century folk still could read Richardson. It follows that the tests judicially used should come from literature itself. In the end books should be judged by books, the law acting merely as the agent of literature. And in adopting this test the courts should refer to the description which literature gives of herself.

The description need not be repeated here in its many forms of expression. Perhaps an easier method is to judge literature by what it is not. The point was made once by Irvin $\mathrm{S}$. Cobb in an after dinner speech, when he mentioned the kind of stuff that bad little boys-and grown-up cubs, too-write on back fences. An illustration is afforded by a recent Federal case where the defendant, in introducing his wares, wrote:

"I have a good line of merchandise that if we were in some barnyard together we could express our views on each item . . . Here's my list of Hayloft Favorites . . . The most beautiful photos in the

$\cong$ People v. Brainard, I92 App. Div. 8I6, I83 N. Y. Supp. 452 (1920) ; U. S. v. Males, supra note 27 ; U. S. v. Clarke, 43 Fed. 574 (S. D. Iowa I890); Halsey v. N. Y. Society, etc., 234 N. Y. I, I36 N. E. 219 (I922). In the case of Mr. Cabell's Jurgen the court directed a verdict of acquittal because, as a matter of law, the book did not offend against the statute. The opinion of Nott, J., is reported in ERNST AND SEAGLE, op. cit. supra note I2, at 29I.

${ }^{\infty}$ St. Hubert's Guild v. Quinn, supra note 88 ; Halsey v. N. Y. Society, etc., silpra note 29. 
world (etc.) . . . Reading books that should have thrilled old King Solomon in all of his glory or even old Nero the reprobate." 31

It is useless to pursue this matter further; no one who cares for books needs a definition of literature. He knows what he is after without the aid of Funk \& Wagnalls. But how necessary it is for the courts to apply to a book these tests of literature, and only these tests, is shown by what happened when Lord Eldon felt otherwise. His record, when it came to pronouncements on matters literary, well justified Sidney Smith's description of the early days of the nineteenth century as being the time when "Lord Eldon and the Court of Chancery pressed heavily on mankind." For this judge, so great in other things, judicially condemned Southey's Wat Tyler and Byron's Cain, and narrowly missed a doubt as to the standing in law of Paradise Lost. ${ }^{32}$ In that regard his action fulfilled the prediction of a competent expert. Sir Walter Scott, when asked by Byron's publisher whether Cain, then in proofs, could be dedicated to him, replied:

"I accept with feelings of great obligation the flattering proposal of Lord Byron to prefix my name to the very grand and tremendous drama of Cain. Some part of the language is bold and may shock one class of readers whose tone will be adopted by others out of affectation or envy. But then they must condemn the Paradise Lost if they have a mind to be consistent. The fiend-like reasoning and bold blasphemy of the fiend and of his pupil lead exactly to the point which was to be expected-the commission of the first murder, and the ruin and dispair of the perpetrator."

"Such," adds Lockhart, in his Life of Scott, "was Sir Walter's opinion of the drama which, when pirated, Lord Eldon refused to protect. It may be doubted if the great Chancellor had ever read Paradise Lost." That is not fair to the old gentleman, for when he decided the case of Byron's book, Lord Eldon stated that he had read Paradise Lost and that too, in the previous Long Vacation. ${ }^{33}$ It is also fair to add that Lord Eldon did not stand alone in his literary views. Previously two different juries (although under strong judicial coaxing) had condemned sellers of Paine's Age of Reason; ${ }^{34}$ and, guided by these precedents, a more enlightened judge, Lord Denman, felt himself compelled likewise to act with a jury in the case of Shelley's Queen $M a b$, although the publisher was never sentenced. ${ }^{35}$

\footnotetext{
${ }^{3}$ O'Neall v. U. S., 56 F. (2d) 5I (C. C. A. 7th, I932).

32 Southey v. Sherwood; Murray v. Benbow, both supra note I8.

33 "You have alluded to Milton's immortal work; it did happen in the course of last Long Vacation, amongst the solicitae jucunda oblivia vitae, I read that work from beginning to end." Lord Eldon in Murray v. Benbow, supra note I8.

${ }^{34}$ Eaton's Case; William's Case, both supra note ro.

${ }^{35}$ Moxon's Case, 2 Townsend's State Trials 356 (184r). Lord Denman's biographer says that the publisher never received sentence after the verdict. 2 ARNOLD, LIFE OF LORD Chief Justice Denman (1874) IO2.
} 
If then literature must be allowed to answer the question in her own way, a writing is to be judged by itself as a whole, not by isolated portions. And so, despite remarks that have appeared to the contrary in some cases, ${ }^{36}$ that is the rule in New York today. "No work," says the Court of Appeals, "may be judged from a selection of such paragraphs alone. Printed by themselves they might, as a matter of law, come within the prohibition of the statute. So might a similar selection from Aristophanes or Chaucer or Boccaccio, or even from the Bible. The book, however, must be considered broadly as a whole." ${ }^{37}$ Such was always the rule in a prosecution for libel; and that, too, whether the prosecution was based on the book as a whole or on isolated paragraphs. ${ }^{38}$ An object of the "Clean Books Bill", of the type vainly offered in our legislatures a decade ago, was to abolish this rule and require the condemnation of a whole book because of an isolated sentence; but the effort failed.

It remains, in this connection, to speak of the young person. Must there be limitations on books which, while literature, yet are not fit for the immature? It has often been contended that such is the law, and yet when we examine the source of these statements we find quite a different situation. It all goes back to an English case where Lord Cockburn, then Lord Chief Justice, stated that a book is illegal if it excites a certain sort of feeling in any sort of reader into whose hands it might happen to fall. For this he has been unsparingly condemned. ${ }^{39}$ Undoubtedly if Lord Cockburn's words are to be taken at their full value, he has much to answer for; yet it is impossible to consider that cultivated man of the world as having meant any such thing. The case, in my opinion, is distinguishable as one of those where, in a controversial pamphlet on the subject of religion, "the decencies of controversy", to use the happy phrase dropped by Lord Coleridge some years later, ${ }^{40}$ are not observed. And it is to be noted that New York courts, going further, have declined wholly to follow the English rule of decency in controversy. "So long as a pamphlet merely excites anger or indignation, it is not within the statute; that is the rule." 41 As for all else, the test is the test of art itself, and the young person cannot be considered beyond that point.

${ }^{\infty}$ Reg. v. Hicklin; Steele v. Brannan, both supra note 27 ; U. S. v. Bennett, supra note 28; U. S. v. Clarke, 38 Fed. 732 (E. D. Mo. I889). There was once such a suggestion by a lower court in New York (People v. Muller, 32 Hun 209 (N. Y. 1884)), but the Court of Appeals, though affirming the judgment, did not adopt the thought, People v. Muller, supra note 28 .

${ }^{3}$ Halsey v. N. Y. Society, etc., supra note 29.

${ }^{2}$ Fitzpatrick's Case, 3I How. St. Tr. I170 (1813).

${ }^{2}$ Reg. v. Hicklin, supra note 27 . For criticism, see ERNST ANd SEAGLe, op. cit. supra note 12 , at $128 f f$. (1922).

${ }^{40}$ Reg. v. Ramsay, I5 Cox C. C. 23I, 235 (1883) ; see also Gott's Case, I6 Cr. App. R. 87

¿ People v. Eastman, I88 N. Y. 478, 8I N. E. 459 (I907) ; U. S. v. Males, supra note 27. 
So much, then, for censorship in both its phases. It is at least clear that, in one form or another, censorship is a feature of our common law system. But, as I said at the outset, this frame that encloses us, beneficial as it may be in supporting certain weak limbs or tissues, can be harmful if it is so tightened as to press unduly upon others. And it has been tightened most strenuously within our own era, as able writers have observed. ${ }^{42}$ I mentioned at the outset the Great War and what it did for us in this regard; but now let me mention one or two details.

We celebrated our entrance into the Great War with an Espionage Act which now belongs to history; and I leave it to others to say just how closely it resembled the Sedition Act of I798 which called forth the Virginia and Kentucky Resolutions. ${ }^{43}$ For my purpose I am more interested in the fact that during the period that intervened between the close of that struggle and the grand crash of I929, this country was beset with all sorts of schemes, some of which went into effect, for governmental regulation of our life and thought. These plans took a wide range. There was the provision of the Volstead law, which forbade the use of the word "beer" in advertising or signs; there was the effort at legislation to prevent our people from being evolution-conscious; there was the endeavor to force all citizens to send their children to the state's schools, and so on. I can remember when the motion picture people, in an endeavor to appease the rulers of our thought, so mutilated literature as to present one of Kipling's masterpieces as the story of a man who lived with a native woman indeed, but in wedlock from the outset, with due rites of the Church of England. Again, I recall that the New York Bar Association just did save the state from a bill presented in the legislature at the session of 1923 which, as the Association's committee said, "if taken literally might well have rendered impossible the teaching of American or at least of revolutionary history." For that bill, among other things, undertook to forbid the use of any textbook in public or high schools which would "contain any matter or statements minimizing or belittling the extent, importance, or effectiveness of American military or naval participation in any military or naval combat, engagement or operation in the Revolutionary War." In short, it would be unlawful for a high school teacher to refer to General Upton's Military Policy of the United States, or Charles Francis Adams' article, contained in his Essays Military and Diplomatic, on Washington as a strategist; for both of these authors, although one hundred per centers as to all breeding requirements, most

${ }^{42}$ Of the many books of recent date, perhaps it will be enough to refer the reader to Frankfurter and Green, The Labour Injunction (1930); Maury, The Wars of the Godly (1928); Chafee, The InQuiring Mind (1929); Hays, Let Freedom Ring (x928). Reference has already been made to the book ERNST AND SEAGLE, To THE PuRE (I929). See also American Mercury v. Chase, 13 F. (2d) 224 (Mass. I926).

${ }^{4}$ See Masses Pub. Co. v. Patten, 246 Fed. 24 (C. C. A. 2d, I9I7), rev'g Judge Learned Hand, 244 Fed. 535 (S. D. N. Y. I9I7). See The Espionage Cases, Note (I919) 32 Harv.

L. REv. 417 ; CHAFEE, op. cit. supra note 42 ; BuRDICK, op. cit. supra note 7. 
seriously belittle the extent, importance and effectiveness of our participation in various combats and campaigns of the Revolution. Yet that bill might have passed had some one not arisen to oppose it, just as bills regarding the teaching of evolution did pass in other states. Let me mention also another bill offered at the same session of the legislature of New York. This, the "Clean Books Bill", undertook to amend the existing law of New York regarding the prosecution of publishers of improper books. Displeased with decisions of the New York courts to the effect that such books as Gautier's Mlle. de Maupin were not illegal because they complied with recognized standards of literature, it was proposed to "put teeth" into the law by means of provisions which I have already mentioned.

Now, since the vast majority of our people (and therefore our statesmen) have returned from those wanderings, should we not forget what has happened? Gladly, would be the answer if any one of us could be sure in his heart that nothing of the sort will ever happen again. But there is too much resemblance between recent occurrences and the evils of the bad old days for one to be quite comfortable. One instance will suffice. In Stuart times, when books and presses were licensed and therefore bootlegging and graft were rampant, a publisher of the period thus memorialized the Secretary of State:

"In January following I had the second impression printing of a book entitled, 'A Treatise of Baptism (etc.)' to which was both the author's and my own name and sign. This book having passed the first impression under some countenance of Dr. Parker (Bishop of London) and the licensed catalogue of books published every term, nevertheless one Mr. Mearn (and) Mr. Vere, two messengers, beadle and porter to the company of stationers, entered my house without a civil officer, and searched every room as well as my warehouse, for the said book; Mr. Mearn having but newly before, in his uncharitable diligence, seized near two thousand sheets of the said book . . . but Mr. Mearn said he would have them into his own custody and damask or spoil them." 44

Instead of a treatise on baptism, of which the authorities disapproved on doctrinal grounds, substitute a case of beer, of which until lately the authorities have disapproved, some on moral and others on doctrinal grounds, and you have a modern raid.

It should also be remembered these periods of excess always leave a scar. In our squirmings we are apt to destroy things; hence when we come out of the fit, there is damage to be repaired, if possible. The Volstead law is going; but some of the Supreme Court's decisions as to the liberty of the individual will remain to plague us. So the custom of authors in giving their manuscripts to the Stationers' Guild for printing, publication and

"Smith's Case, 7 How. St. Tr. at 952 (I680). 
selling, with the right in the author to assign his interest to any one whom the Guild might accept in his place, supplied the complete idea of copyright. Hence, if only the Tudors, Puritans and Stuarts had left the situation alone the assertion, constantly made in the English courts but not fully supported, ${ }^{45}$ that modern copyright is essentially of a common law nature, might have been true; and neither author nor publisher would have to look to a statute as his sole bulwark against the pirate. But with the passing of the monopoly held by Stationers' Hall - a monopoly originally innocent, as we saw, but perverted by Government to press censorship-with the passing of that monopoly, what became of the author's rights? That question was so formidable that Parliament had to remove it by the Copyright Act of I 09 , to which modern legislation and all actual rights as well are traced. ${ }^{46}$

Let us also remember that zealotry takes many forms and makes strange bedfellows. We should not forget that Calvin not only caught Servetus, but was able successfully to prosecute him to a fiery death, on information and evidence furnished by the Spanish Inquisition. ${ }^{47}$ I do not imagine that Mr. Volstead shared many of the aspirations of Archbishop Laud, yet when the national prohibition law made federal courts aid in the enforcement of prohibition by way of "padlocking", we were not far away from the Star Chamber. To my mind, therefore, we had better continue in a wholesome state of watchfulness, for who knows what may break loose again? One of our poets said that when in the shadow of a Spanish palace he could fancy "Torquemada lingering near". This man, although the first Grand Inquisitor of Spain, was much more a nationalist than a churchman, as some modern historians have pointed out. His kind reproduces itself. And so, despite all our Jeffersons and Franklins, yet in the shadow of our capitols and departmental offices we should have constant regard for the menacing presence, not of Torquemada, but of people like him.

${ }^{45}$ See Miller v. Taylor, 4 Burr. 2303 (I769) ; Jeffreys v. Boosey, 4 H. L. Cas. 8I5 (I854).

4o Stat. 8 AnNe c. Ig. See Holdsworth, supra note 2.

"It See MCDonall, Historical. TrLals (Igz7), and review by Chafee, Book Review (I929) 4I HARV. L. REv. 4IO, 4I2. 